\title{
Radosław Kamiński
}

Wyższa Szkoła Bankowa we Wrocławiu (Poland)

\section{The State and Local Self-Government. Territorial Organization of the State}

\begin{abstract}
Local self-government constitutes a part of executive power in the state, with the state's law underlying its functioning. Local government remains under the state's supervision, representing a form of the political system within the decentralized public administration. 2018 marks 20 years of the functioning of local self-government based on a three-tier structure. The aim of the paper is an attempt at finding the answer to the question whether or not the organizational solutions adopted by the legislator and established in practice need to undergo reforms and if so, to what extent? The question thus formulated relates directly to the argument that the organization of local government system is not sound while the criteria assumed in the territorial breakdown of the local government organization do not correspond to the conditions in which those units operate, and therefore what appears necessary is for the system to be reorganized and the number of units at individual tiers to be reduced. The paper presents selected problems of the local administration in the context of a systemic organization and suggest possible (or necessary) changes which, in the author's view, should become a subject of discussion (and in practice are such) between local selfgovernment and government administration.
\end{abstract}

Keywords: public administration, decentralization, territorial break down, administrative reform, local self-government

\section{Introduction}

In Poland, the end of 2018 will have seen the two decades coming to an end during which local government has been functioning based on a three-tier structure. It is a period that is long enough and sufficient for launching a synthetic analysis aimed at assessing the solutions adopted in 1998, which - with the exception of a few changes implemented during that time - have been in place for 20 years. The issues surrounding the functioning of local government in the Third Republic of Poland were invariably an element of discussion and discourse among politicians, lawyers, local authorities and the public itself, with all of them 
- despite their considerable differences as regards many aspects -agreeing that without local government a rapid growth of the country and the development of civil society would not be possible. It is, however, hard not to notice the myriad of problems connected with the functioning of local government, which is often manifested by a bitter dispute, a growing difference of opinion, criticism of the solutions adopted and a proposal of reforms.

Still, it should be stated clearly that a critical view of local government and other aspects involved in public administration is not the exclusive preserve of Poland. Today numerous authors speak about the dysfunctionality of specific solutions operating in different systems and about a crisis of the democratic state (Boudon, 2009). With respect to the functioning of local government, there are currently two types of objections that are being raised. The first one - as S. Mazur observes - refers to "the low effectiveness and efficiency of its actions and an unsatisfactory quality of the public services it provides. The second objection is associated with the erosion of the principles and mechanisms of local democracy, in particular those relating to the citizens' involvement in the affairs of local communities. (...) A response to the cited objections were reforms aimed at eliminating those dysfunctionalities. (...) The purpose of the reforms is to economize local governments' activities and to democratize the systems for managing local communities' affairs" (Mazur, 2015, p. 13). According to the author, what they are ultimately led to is attainment of the overriding goal which is to build democratic legitimacy of local government, with a stronger modernization impetus being, however, in general associated with budgetary and financial restrictions.

The aim of the paper is an attempt at finding the answer to the question whether or not the organizational solutions adopted by the legislator and established in practice need to undergo reforms and if so, to what extent? The question thus formulated relates directly to the argument that the organization of the local government system is not sound while the criteria assumed in the territorial breakdown of the local government organization do not correspond to the conditions in which those units operate, and therefore what appears necessary is for the system to be reorganized and the number of units at individual tiers to be reduced. This premise is based on the belief the public administration must adjust itself, also in terms of spatial structure, to the constantly evolving tasks determined by economic, demographic, political, social and technological factors (Knosala, 2006, p. 97).

In the light of the complexity of this issue, the discussion has been confined to the territorial breakdown and organization, and to a synthetic (critical) assessment of the solutions adopted. What also needs to be stressed is the fact that this is not a new academic strand, since it has been the subject of a number of scientific and political analyses in recent years (Bober et al. 2013, Antczak et al., 2013).

\section{The State and Local Self-Government}

Local self-government constitutes a part of executive power in the state, with the state's law underlying its functioning. Local government remains under the state's supervision, 
representing a form of the political system within the decentralized public administration. Through the appointment of local government (but also other forms of self-government), the state narrows down the scope of public responsibilities carried out by the government administration (Kamiński, 2012,p. 57). The functioning of the local self-government is one of the key elements allowing to recognize a regime as democratic.

Self-government - endowed with a legal personality that is separate from the state reflects the recognition of a plurality of diverse interests within the state and the abandoning of the principle of the absolute primacy of the overall state interest, with the allocation of tasks between the state, as a political and legal entity, and the "empowered" local governments depending on a number of factors. The main criterion for the allocation of tasks has traditionally been the "local nature" of the responsibilities of local governments and their association with meeting collective needs of a local community (Kamiński, 2014b, p. 7). M. Jaroszyński’s assertion has lost nothing of its relevance when he observed that "local government consists in making local factors (naturally within the limits of the law) independent from the central authorities, which allows local government to prevent excessive centralization; secondly, in its organization, local government takes into account the civil element, as broadly as possible, appointing it to making decisions on public matters, which is the best way to hamper excessive bureaucracy (Jaroszyński, 1990, p. 8).

By definition, decentralization engenders specific effects at the following dimensions:

- the financial one, through devising a mechanism for a rational and cost-effective use of public resources available;

- the social one, reflected in the mobilization of the public to take actions with a view to gain specific benefits;

- the political one, contributing to the "decentralization of conflicts" as a result of the local government replacing the state as the first addressee of specific demands (Kulesza, 1994, pp. 3-4).

The political transition initiated in 1989 covered largely the public administration system, which - following its functioning under a totalitarian political system for nearly half a century - as a centralized system became highly dysfunctional, little flexible and failing to carry out public responsibilities appropriately. The system was a formidable obstacle to implement any changes, which made a fundamental reform of the public administration a self-evident requirement.

Establishing local government at the commune tier and - most importantly - conferring on it constitutional rank ${ }^{1}$ initiated the decentralization process of the public administration in Poland, which in the long run was to be bring about reduced competences of the central government to the benefit of local government authorities, the country's rapid development,

1 Articles 43-47 of the Act of 8 March 1990 on amending the Constitution of the Republic of Poland (J.L. 1990, no. 16, item 94) 
effective performance of public duties and the development of communities at the grass-root level. The empowerment of communes became thus the first political reform of the Third Republic of Poland (Kamiński, 2014a, p. 70), with the 1998 reform being its continuation and completion. The said reform complemented the local level with self-governing poviat (district) and introduced a government at a regional level through establishing self-governing voivodship (region/province).

Its essential goals were set out as follows:

- increased efficiency and effectiveness in terms of the operations of public administration offices, provision of public services and public finance management at the local (poviat) and regional (province) level, through, for example, shaping rational spatial structures which respect ecosystems and cultural heritage,

- reorganization of the country's territorial organization and the structures of local government and adapting it the European Union standards, which was to allow for using the EU legal and economic instruments to be available in the future,

- adapting public administration to the requirements of a unitary democratic state upholding civil rights and the rule of law and to establish civil society institutions at a local and regional level (Informacja, 1999; Gilowska et al., 1997; Wysocka, Koziński, 1998).

Setting these goals implied that what would be striven for was to create possibly most efficient and most rational structures of public administration, both in terms of territory and functionality, i.e. endowing the newly established units with broad competences and an adequate position in the system of public finance (Kamiński, 2014a, p. 71).

As a result, following much bargaining going on the parliamentary stage and beyond, which sadly was determined by numerous irrational factors, a three-tier local government was established, which - following the assessment of the new territorial division in 2000-2001 and the subsequent changes implemented by the Ordinance of the Council of the Ministers altering the shape, size and number of units - was structured according to the following levels:

- commune: 2478 communes (302 urban communes, 621 urban-rural communes, 1555 rural communes),

- district: 380 districts (314 rural districts, 66 towns with district rights),

- province: 16 provinces-regions (as of December 31,2017).

At present, the analysis concerned with the functioning of local government units in a three-tier system is multifaceted, mainly coming down to the issues relating to the following aspects:

- territorial division and organization,

performance of public duties in their broad sense, particularly considering direct responsibilities of local governments,

- finances and communal property,

- human resources management, 
- creative and developmental function,

- the scope and manner of conducting supervision.

All these issues make up a set of inter-connected elements, jointly affecting and determining the functioning of local government, which find their direct reflection in the performance of public duties entrusted to local government units and the functioning of communities that is in accordance with public interest.

\section{Territorial Organization and Division, and the Ability and Effectiveness of Public Duty Performance}

While approaching the synthetic analysis of the solutions adopted 20 years ago, it should be noted that the system of local government implemented by the legislator is very categorical in its nature, evincing little flexibility, which, among other things, is evidenced in the uniform solutions applied to self- government at the local level (commune, district). With respect to communes, this is, on the one hand, about the fact that rural communes are not different under law from urban communes, which, after all, differ significantly from one another in plenty of aspects (e.g. the functional aspects and the abilities to perform public tasks). On the other hand, this also pertains to their operations (specifically: the rationale) of so called "bagel-shaped" communes (those surrounding a city or town) of which currently there are no less than 157, with 144 of them forming a pair with an urban commune, and 13 with a town with district rights ${ }^{2}$. In a likewise situation are districts, with the main issue here being their size diversity which is not based on uniform criteria, and further on, the rationale behind establishing the "bagel-shaped" districts (at least some of them) and the development potential of a town which is the capital of a district. In the light of these considerations, what should be highlighted is the fact that 12,62 million people currently live in towns with district rights, which makes up nearly $33 \%$ of Poland's population ${ }^{3}$. These data show de facto that every third of the country's residents functions in a two-level, and not the three-level structure, considering that this unit plays simultaneously the role of a commune and that of a district, while institutionally it is the same as the principal unit (Articles 91 and 92 of the Local Government Act). What should further be highlighted is that almost 5,1 million people (13,2\% of the entire population) live within the areas of the bagel-shaped districts, which in their size approximate the towns with district rights (powiat grodzki) to which they

2 This number was reduced on January 1, 2015, when the town of Zielona Góra was joined with the adjacent rural commune (Ordinance of the Council of Ministers of 29 July 2014 on joining communes, setting borders of some communes and towns, granting some localizations the status of a town and on changing the seat of commune authorities, J.L. 2014, item 1023).

3 The author's own calculations based on the GUS (central Statistical Office) data for 2016 (Powierzchnia i ludnosśc...). 
are adjacent ${ }^{4}$, yet quite frequently lack adequate infrastructure necessary for implementing the tasks appointed to them by the legislator (e.g. health care).

The consecutive aspect refers to the size of individual units of the country's basic territorial breakdown. The model that is today in force is the outcome of a discussion held in 1998 which although ended in reaching a socio-political consensus, in hindsight assessing it as clearly positive might be difficult, given that the local government map which was then created shows drastic disparities between the sizes of individual units (Kamiński, 2014a, pp. 75-77). This is illustrated by the data included in Table 1 .

Table 1. Population in rural-urban communes and in rural communes

\begin{tabular}{llllll}
\hline $\begin{array}{l}\text { Total number } \\
\text { of urban-ru- } \\
\text { ral, and rural } \\
\text { communes }\end{array}$ & \multicolumn{5}{l}{ Population of urban-rural communes and rural communes } \\
\cline { 2 - 6 } & less than 2000 & $\mathbf{2 0 0 0 - 4 9 9 9}$ & $\mathbf{5 0 0 0 - 6 9 9 9}$ & $\mathbf{7 0 0 0 - 9 9 9 9}$ & $\begin{array}{l}\mathbf{1 0 0 0 0} \text { and } \\
\text { more }\end{array}$ \\
\hline 2177 & 32 & 747 & 565 & 450 & 383 \\
\hline
\end{tabular}

Self-reported data based on Ludność. Stan i struktura w przekroju terytorialnym w 2017r. Stan w dniu 31.XII.2016r., Central Statistical Office, Warszawa 2017, at: http://stat.gov.pl/obszary-tematyczne/ludnosc/ludnosc/ludnoscstan-i-struktura-oraz-ruch-naturalny-w-przekroju-terytorialnym-w-2017-r-stan-w-dniu-31-xii,6,23.html

The data clearly show that there are large differences in terms of the size of population across individual units. At this point one should note that in the urban-rural communes and in the rural communes over 15,2 million people live, which makes on average 7 thousand people, with $1344(61,85 \%)$ communes having a population that is below the average, while 334 have less than 4 thousand people, among which no less than 103 have less than 3 thousand people. What is further noticeable is the fact that some of those communes share a border and jointly their population is still no more than 5-6 thousand ${ }^{5}$. In 302 urban communes their total population is at 23,1 million, which means that an average urban commune has 76 thousand population. The communes differ also in terms of population density which seldom is on account of geographical determinants ${ }^{6}$.

For districts - just like for communes - the differences are also considerable in terms of population and area, as presented in Table 2.

4 The author's own calculations based on the GUS (central Statistical Office) data for 2016 (Powierzchnia i ludność...).

5 The following communes can be mentioned here: Nur and Boguty-Pianki in Ostrowski district; communes Regnów and Cielądz in Rawski district; Podedwórze and Jabłoń in Parczewski district.

6 What also appears irrational is the measure adopted on the number of councillors in individual communes (districts as well). Actually, whatever the size, the number of councilors is actually the same which is 15 (for 2140 communes). 
Table 2. Population across districts

\begin{tabular}{lllllll}
\hline $\begin{array}{l}\text { Number of } \\
\text { districts }\end{array}$ & Population & & & & & \\
\cline { 2 - 7 } & $\begin{array}{l}\text { less than } \\
\mathbf{3 0 0 0 0}\end{array}$ & $\begin{array}{l}\mathbf{3 0 0 0 0 -} \\
\mathbf{4 9 9 9 9}\end{array}$ & $\begin{array}{l}\mathbf{5 0 0 0 0 -} \\
\mathbf{7 9 9 9 9}\end{array}$ & $\begin{array}{l}\mathbf{8 0 0 0 0 -} \\
\mathbf{9 9 9 9 9}\end{array}$ & $\begin{array}{l}\mathbf{1 0 0 0 0 0 -} \\
\mathbf{1 4 9 9 9 9}\end{array}$ & $\begin{array}{l}\mathbf{1 5 0 0 0 0} \\
\text { and more }\end{array}$ \\
\hline Land districts 314 & 5 & 62 & 119 & 47 & 57 & 24 \\
\hline $\begin{array}{l}\text { Towns with district } \\
\text { rights: 66 }\end{array}$ & - & 5 & 16 & 6 & 16 & 23 \\
\hline
\end{tabular}

Self-reported data based on Ludność. Stan i struktura w przekroju terytorialnym w 2017r. Stan w dniu 31.XII.2016r., Central Statistical Office, Warszawa 2017, at: http://stat.gov.pl/obszary-tematyczne/ludnosc/ludnosc/ludnoscstan-i-struktura-oraz-ruch-naturalny-w-przekroju-terytorialnym-w-2017-r-stan-w-dniu-31-xii,6,23.html

No less than 260 districts have population of less than 100 thousand, while one should recall the fact that a statistical district has a population of 101 thousand, which means that roughly only one in three districts is above average (sic!). In the context of the 1998 reform, another puzzling aspect is the number of districts with population less than 50 thousand (72 districts, which makes up $19 \%$ of the total) $)^{7}$. If we leave out towns with district rights (66), than a statistical land district has 82,3 thousand population with a population density of 85 inhabitants per $\mathrm{km}^{2}$ against 192,3 thousand population and population density of 1768 inhabitants per $\mathrm{km}^{28}$. Considering the data, one should also refer to them through the prism of the initial premises underlying the reform devised by the Sejm (parliament) of the first term headed by Michał Kulesza, at that time the Government Plenipotentiary for the Public Administration Reform. The premises envisaged 120 administrative regions which in the future were to complement self-government at the local level, but ultimately 265 administrative regions were established (Kamiński, 2014b, p. 127).

Interesting conclusions can also be inferred from the comparison presented in Table 3. It shows the population of cities with district rights which are capitals of provinces and of bagel-shaped districts?.

7 One should bear in mind that in 1998 the during the process of establishing districts the government - being endowed by way of the ordinance with the right to appoint them independently - enjoyed a considerable latitude in their actions. However, convinced that territorial ties at a district level were much stronger, the government drafted the district map while conducting broad public consultations, which led to a considerable number of districts. The criteria pertaining to the potential of the proposed district units were to play an auxiliary role. it was assumed that a district should have at least 50 thousand population and cover the area of at least five communes, while a town/city where the district authorities were based had to have at least 10 thousand inhabitants (Podstawowe kryteria...; Kulesza, 1998; Powierzchnia...).

8 The author's own calculations (Powierzchnia...).

9 Because of the specific solution adopted for the following provinces: Kujawsko-Pomorskie and Lubuskie, the table includes the seats of Voivodes and of Marshall Offices. 
Table 3. Population in towns with district rights and in bagel-shaped districts

\begin{tabular}{lccc}
\hline Province/town/land district & Population & & \\
\cline { 2 - 4 } & Town & Land district & Total \\
\hline Mazowieckie (Warsaw) & 1744351 & - & 1744351 \\
\hline Małopolskie (Cracow, Krakowski district) & 761069 & 270490 & 1031559 \\
\hline Wielkopolskie (Poznań, Poznański district) & 542348 & 366037 & 908385 \\
\hline Łódzkie (Łódź, Eastern Łódzki district lódzki) & 700982 & 70430 & 771412 \\
\hline Lower Silesian (Wrocław, Wrocławski district) & 635759 & 134145 & 769904 \\
\hline Pomorskie (Gdańsk, Gdański district) & 462249 & 109394 & 571643 \\
\hline Lubelskie (Lublin, Lubelski dsitrict) & 340727 & 151178 & 491905 \\
\hline Zachodniopomorskie (Szczecin, Szczeciński district) & 405657 & 78578 & 484235 \\
\hline Kujawsko-Pomorskie (Bydgoszcz, Bydgoski) district) & 355645 & 112992 & 468637 \\
\hline Podlaskie (Białystok, Białostocki district) & 295981 & 145517 & 441498 \\
\hline Świętokrzyskie (Kielce, Kielecki district) & & & \\
\hline Podkarpackie (Rzeszów, Rzeszowski district) & 198046 & 208526 & 406572 \\
\hline Kujawsko-Pomorskie (Toruń, Toruński district) & 185896 & 167342 & 353238 \\
\hline Śląskie (Katowice) & 202689 & 103397 & 306086 \\
\hline Warmińsko-Mazurskie (Olsztyn, Olsztyński district) & 299910 & & 299910 \\
\hline Opolskie (Opole, Opolski district) & 173444 & 123479 & 296923 \\
\hline Lubuskie (Zielona Góra, Zielonogórski district) & 118931 & 133048 & 251979 \\
\hline Lubuskie (Gorzów Wielkopolski, Gorzowski district) & 138711 & 75219 & 213930 \\
\hline
\end{tabular}

The author's own study (Ludność...).

Analyzing these data, the fact should be stressed that towns with a population, together with bagel-shaped districts, exceeding 400 thousand in vast majority are growth centers in Poland attracting the highest number and the biggest investors. These centers tend to offer the highest level of services, access to well-developed higher education institutions, scientific research, culture while also ensuring high quality services in healthcare and education. They are also centers providing the best infrastructural solutions. What is of import here is that the development of bagel-shaped districts is largely on account of these centers and the seats of their offices and access to some of the public services is exclusively in province cities. Despite this fact, it is not always possible to work out adequate patterns of operations and cooperation between those units, which seems to be a clear confirmation of the need to devise new system solutions in this area.

With respect to the self-governing provinces, the disparities are also quite large. According to the premises of the reform, a region covering a large area enjoying a strong economy, capable of running regional and interregional policy, as well as its own development policy was to contribute to the decentralization of the state (Grzybowska, 2013, pp. 648-649). Moreover, it was to accelerate economic growth, strengthen Poland's international position and adapt the Polish territorial structures to the EU standards in the context of using the 
mechanisms for supporting regional and local initiatives and cross-border cooperation (Kamiński, 2014b,p.133). A political and extra-parliamentary dispute centered on provinces (their number and size) was held at the time of the legislative changes unfolding in 1998. The concept of 12 regions that was originally proposed failed to be forced through by the coalition majority and eventually 16 smaller units were established, as illustrated in Table 4 .

Table 4. Population in provinces

\begin{tabular}{lccccc}
\hline $\begin{array}{l}\text { Total } \\
\text { number of } \\
\text { provinces }\end{array}$ & \multicolumn{4}{l}{ Province population } & \\
\cline { 2 - 6 } & $>=\mathbf{1 , 5} \mathbf{~ m l n}$ & $\begin{array}{l}>\mathbf{1 , 5} \mathbf{~ m l n} \\
<=\mathbf{2 , 5} \mathbf{~ m l n}\end{array}$ & $\begin{array}{l}>\mathbf{2 , 5} \mathbf{~ m l n} \\
<=\mathbf{4 , 0} \mathbf{~ m l n}\end{array}$ & $>\mathbf{4 , 0} \mathbf{~ m l n}$ & $\begin{array}{l}\text { average } \\
(>\mathbf{2 , 4} \mathbf{~ m l n})\end{array}$ \\
\hline 16 & 5 & 5 & 4 & 2 & 6 \\
\hline
\end{tabular}

Self-reported data (Ludność...).

Looking at the size of provinces, we can observe that no less than $1 . / 3$ of them exceeds a population of 1,5 million $^{10}$. On average, a province covers an area of $19543 \mathrm{~km}^{2}$ and has 2 406,5 thousand inhabitants, which means that only six regions are above the average. The 16 provinces are also rather differentiated in terms of their area size and population, as well as population density. According to the size of the territory they cover, the biggest province is Mazowieckie $\left(35,7\right.$ thou. $\left.\mathrm{km}^{2}\right)$ and Wielkopolskie $\left(29,8\right.$ thous. $\left.\mathrm{km}^{2}\right)$. The smallest ones are Opolskie $\left(9,4\right.$ thou. $\left.\mathrm{km}^{2}\right)$ and Świętokrzyskie $\left(11,7 \text { thou. } \mathrm{km}^{2}\right)^{11}$.

If we consider the structure of revenues generated in a province government, one should notice the extent to which they have changed over the last 20 years, and so whereas at the beginning (up to 2003) over $80 \%$ of revenues was made up of subsidies and earmarked grants, in 2016 - following numerous legislative changes - own revenues made up 53,4\% ${ }^{12}$ in the revenue structures of provinces in total (Bober et al., 2013, p. 47; Sprawozdania, [Reports] 2007-2016). On the revenue side, what makes a significant share are grants provided within the framework of programs financed with the involvement of European funds and other foreign non-reimbursable funds and payments from the European fund budget. In 2015, these resources accounted for 30,25\% of total revenues, while in 2016 it

10 If we assume that large are the provinces with 2,5 million population (above average), then there are only six of those, with the most populous being the following provinces: Mazowieckie 5300 thou.), Śląskie (4616 thou.). At the other end are Lubuskie (1023 thou) and Opolskie (1010 thou.)

11 Very large disparities can also be recorded in terms of population density per $\mathrm{km}^{2}$ (the average is 123 persons $/ \mathrm{km}^{2}$. It develops as 1:6,2. It is determined by a particularly high employment rate in Śląskie province -347 persons $/ \mathrm{km}^{2}$. and very low in Warmińsko-Pomorskie province -60 persons $/ \mathrm{km}^{2}$. The following province have above average density of population: Śląskie, Małopolskie (221), Mazowieckie (149), Dolnośląskie (146) and Łódzkie (139).

12 It should be emphasized that these are basically only shares in taxes constituting state budget income, and their imposition, collection and amount of tax rates are not dependent on local self-government units (regional self-government). 
was almost 18 \% (Sprawozdanie, 2016). Establishing self-governing provinces in 1998 was, inter alia, determined by Poland's accession to the European Union, which in some sense "legitimized" their functioning.

Analyzing the operations of a province self-government, one should highlight the fact that the local government administration bodies operate across this area. The duality of power at this tier, or at least the scope of competences conferred on the entities is attributable to a number of disputes engendered by a "political rivalry" thus failing to foster effective development (Bober et al., 2014, p. 35).

Referring to these data, one more issue has to be mentioned. It pertains to the possibility of cooperation between the units at individual tiers, and in the first place it is about the fact that no possibility exists of creating associations ofon the metropolitan union which would allow for providing broader and more comprehensive public services, thus reacting to numerous problems encountered nowadays by local governments, while at the same time using the available resources more effectively and solving the problems faced by local communities more efficiently.

Another valid issue referring directly to the size of self-governing units is connected with the demographic processes unfolding (Gwiazda, 2015; Prognoza...). There is no doubt that the demographic trends do not bode well as they indicate the risk of depopulation of some communes, districts and regions, which will, in the long run, undoubtedly affect adversely the potential for development of many local government units and will change the taskbased structure. "The mass migration of people - as R. Gawłowski argues - globalization, new challenges related to the computerization of administration, which has the effect that the provision of services is becoming de-territorialized calls for reconsidering the principal territorial breakdown grid of the country, as well as special breakdowns" (Gawłowski, 2012, p. 164). Indeed, in view of the processes unfolding what is clearly to change is the way and scope of public service provision, predominantly regarding the responsibilities within the area of healthcare and social assistance.

Another issue is concerned with the so called categorical three-tier structure of local government. The legislator - although there were no formal (constitutional) reasons - did not allow for creating other administrative units, e.g. metropolitan areas. That the Act on Metropolitan Association came into force for Śląskie province ${ }^{13}$ is by no means a comprehensive solution of this problem neither in terms of competences nor in the organizational aspect.

Another element that is important and which many authors consider to be paramount and determining all others, is the issue surrounding the scope, method and the level of

13 The Act of 9 March 2017 on Metropolitan Association in Śląskie province (J.L. 2017, item 730). With coming in force of this act, which repealed on April 7, 2017 the Act applicable as of October 9, 2015 on Metropolitan Associations (J.L. 2015, item 1890) to which no implementing acts were ever passed, thus in fact precluding any possibility of establishing metropolitan associations in the country. 
public duty performance by units at the individual tiers and thus directly-related way in which they are funded in conjunction with the state revenue redistribution and raising own revenues. On the one hand, this arises from the constitutional principal of public power devolution (Article 15 of the Constitution of the Republic of Poland), while on the other hand, from "using" local governments by the government administration as a "cheap tool for fulfilling public duties." The range within which self-governing units enjoy their autonomy - by definition independent - is, however, limited by the state jurisdiction. With respect to revenue- generating activity, the competences of local authorities are not entirely autonomous, while the revenue-related autonomy is restricted by the maximum level of revenues generated (Bober et al., 2013, p. 42).

One of the indicators enabling one to assess the autonomy enjoyed by local government units and their growth potential is the percentage of their own revenues in total revenues of a given unit and the percentage of targeted subsidies in the revenue structure. Following the analysis of the data included in Tables 5 and 6 , an interesting conclusion suggests itself

Table 5. Percentage of own revenues in total revenues of communes

\begin{tabular}{|c|c|c|c|c|c|}
\hline \multirow{2}{*}{$\begin{array}{l}\text { Percentage of } \\
\text { own revenues }\end{array}$} & \multicolumn{5}{|c|}{ Province population } \\
\hline & $\leq=20 \%$ & $20,01-40,00 \%$ & $40,01-60 \%$ & $60,01-80 \%$ & $80,01-100 \%$ \\
\hline $\begin{array}{l}\text { Number of } \\
\text { communes }\end{array}$ & 48 & 1078 & 996 & 347 & 9 \\
\hline $\begin{array}{l}\% \text { of communes } \\
\text { in total }\end{array}$ & 1,94 & 43,50 & 40,19 & 14,00 & 0,36 \\
\hline
\end{tabular}

Self-reported data (Sprawozdanie...).

Table 6. Percentage of own revenues in total revenues. Districts and provinces

\begin{tabular}{|c|c|c|c|c|}
\hline \multirow{2}{*}{$\begin{array}{l}\text { Percentage of } \\
\text { own revenues } \\
(\%)\end{array}$} & \multicolumn{4}{|c|}{ Revenues (scope \%) } \\
\hline & Own revenues & PIT-CIT & subsidies & grants \\
\hline Districts & $14-16 \%$ & $14-18 \%$ & $43-46 \%$ & $23-30 \%$ \\
\hline Provinces & $6-10 \%$ & $35-45 \%$ & $14-20 \%$ & $24-55 \%$ \\
\hline
\end{tabular}

Self-reported data (Sprawozdanie...).

The data show clearly that in light of the low percentage of own revenues in total revenues and a high percentage of transfers coming from the state budget, the autonomy and development potential is significantly limited. In particular, this relates to land districts and provinces, as well as rural communes which are the weakest units in the entire sector. This is further evidenced by, for example, the data showing the development activities and investments carried out by local government units (Sawicka, 2013, pp. 283-286). What has to be assessed as a clearly negative development is an increase in earmarked grants in the revenue structure of communes. This is because individual units are becoming dependent on government administration and thus fail to ensure financial security and stability 
(Bober et al., 2013, p. 43). What should be further emphasized is that the percentage of own revenues is in direct proportion to the size of a given local government unit, which is immediately reflected in the percentage of investment expenditures by individual units (Local Data Base).

\section{Recommendations}

It appears that the issue of territorial reorganization is necessary and inevitable. At this point the only question left is one concerning the time perspective. The organizational and institutional reform could contribute to improvement in terms of quality, access and productivity of services provided, better coordination of statutory duties through reducing the number of local governments, better effectiveness of task performance, in particular those which require considerable outlays. The effect that the reform would have would be improved balance achieved by reduced employment and establishing a system of professional staff.20. The reform would certainly reduce the number of posts and councilors. The change in the map of the country's basic territorial division would lead to less pronounced disparities in revenues between individual local government units, a change of the revenue structure and a more objective distribution of costs of public services through making local government borders a reality (Kamiński, 2014a, pp. 80-81).

An important element of the changes in the territorial division would entail the possibility of establishing large rapidly growing metropolitan centers which have de facto already been establishing themselves "from below".

The legislator should also undertake a parliamentary debate focusing on the possibility of establishing communal associations of local government units of different tiers and implementing a "rational financial tool" which would represent an incentive for individual units to start a productive cooperation.

\section{Summary}

The data presented in the paper and the brief and selective analysis certainly prompt a debate that is, after all, quite understandable. As regards the issue in question, the views will differ depending on whether it is a local government official's opinion or that of a politician or persons responsible for devising, carrying out and implementing the local government reform of 1990 and 1998. One of its authors, Jerzy Regulski strongly opposes experts who see efficient governance of the state as a fundamental criterion, saying that in implementing self-governance, the very idea was not to govern the state so as to enable the communes to govern themselves. The number of the country's communes or districts cannot form a criterion for a territorial division. (...). The criterion for shaping the LGU borders can only be the size of a particular unit evaluated from the perspective of its ability to perform public duties" (Regulski, 2013, p. 7). One could, of course, use examples of many countries where 
the number of units and the average population is lower than that in Poland, yet this issue should be looked at through the lens of the differentiated local government models existing in different countries, the perceived role of local authorities, the way they function (competences, finances), as well as the settlement system. A lot of criticism voiced by opponents of consolidation includes an argument stating that the natural bond between the unit and community will be annihilated and local identity will be destroyed, for instance, in that the confidence in public institutions will be weakened, direct supervision will be reduced and so citizens' awareness of their impact on the development and the way a local government unit functions (Ekspertyza...). However, there are arguments - as a counterweight - by those advocating the change asserting that a demographic potential of local governments may (should) be seen as the basis for a rational territorial division, while the matter of social ties and the nature of public services to be rendered should be considered secondary. Although it is not easy to resolve this dilemma, even the opponents of the economic approach speak of the need to implement organizational changes in the system of local government through enlarging the individual local government units (Regulski, 2013, pp.3, 18-19). At this point it is worth quoting a valuable observation made by L. Habuda, who maintains that "weakening the strongest leads to leveling down to those who are weaker, which is damaging to everybody. This solution will impede the development that is expected. It is to the detriment of all, but especially to the weakest who are condemned to lag perpetually behind, unable to close the gap. Opportunities to accelerate growth are not embedded in a race to the bottom, but to the top, to the biggest, richest and strongest" (Habuda, 2012, p. 61).

Does the legislator's embarking on the process of restructuring territorial division make sense and can it ultimately bring some measurable benefits? To these questions the author of this paper (partially documented by the data and examples presented herein) answers in the affirmative, which is also in line with the assessment prepared a few years ago by the Ministry of Administration and Digitization (Ocena sytuacji..., 2013)

From a legal perspective, the implementation of changes is possible, which was confirmed by the Constitutional Tribunal. "In the light of Article 163 of the Constitution, as well as Article 3 of the European Charter of Local Self-Government, and considering the existing jurisprudence of the Constitutional Tribunal, there is no doubt that the stability of specific units of local government within specific borders is not a value that prevails over the reasons of public interest of national nature; in practice it is often that a conflict of interest emerges between that of individual communes and the public interest" (Judgment of the Constitutional Tribunal dated 8 April 2009, file K 37/06, Dz.U. 2009, no 63, item. 532).

What appears, however, of key in that area is the answer to the question: is it to be a local government perceived as a form of organization for community residents, or an effective element of the system of state governance; is it to be a public service provider or an institution responsible for the development of a particular region? At this point Habuda's assertion may seem appropriate as he believes that every territorial division must be tightly related to the structure of local bodies and the roles they fulfill. He argues that "dividing and 
linking the duties involved in those roles should be carried out in such a way as to foster the minimization of costs involved in performing those roles (Habuda, 2012, p. 58). Habuda's observations go hand in hand with the trends observed in recent years in Western Europe seeking to consolidate self-governments, e.g. the Danish reform of 2007, administrative changes in Latvia in 2009 and a decrease in the number of communes in the Netherlands (Kamiński, 2014, pp. 80-81).

At this point, however, what should be made particularly clear, is that in the light of the current political situation largely determined by a rivalry, whose roots are wide and multifaceted, between the two opposing camps, the prospect of implementing comprehensive changes seems very doubtful.

\section{References}

Act of 8 March 1990 on the Amendment of the Constitution of the Republic of Poland j (J.L.. 1990 no 16 item. 94).

Act of 5 June 1998 on District Self-Governemnt (consolidated text. J.L.. 2018, item. 995).

Act of 9 October 2015 on Metropolitan Associations (J.L.. 2015 item. 1890).

Act of (March 2017 on the Metropolitan Association for Śląskie Province (J.L.. 2017 item. 730).

Antczak, R., Dąmbska, A., Glusman J., Herbst K., Kryczka, A., Trzyna, S. (2013). Samorząd 3.0. In A. Dąmbska, S. Trzana (eds.), Raport. Warsaw: Forum Od-nowa.

Baza Danych Lokalnych. Retrieved from: https://bdl.stat.gov.pl/BDL/dane/podgrup/wymiary

Biga, B., Bober, J., Chrabąszcz, R., Gluc, K., Kudłacz, M., Mazur, A., Mazur, S., Olech, J., Sześciło, D. (2015). Sprawne państwo. Reformy samorządu lokalnego w wybranych krajach. In (ed.) S. Mazur. Kraków: Małopolska Szkoła Administracji Publicznej UEK

Bober, J., Hausner, J., Izdebski, H., Lachiewicz, W., Mazur, S., Felicki, A., Nowotarski, B., Puzyna, W., Surówka, K., Zachariasz, I., Zawicki, M. (2013). Narastające dysfunkcje, zasadnicze dylematy, konieczne działania. Raport o stanie samorząności terytorialnej w Polsce, Tom I. Kraków: Małopolska Szkoła Administracji Publicznej, UEK.

Bober, J., Hausner, J., Izdebski, H., Lachiewicz, W., Mazur, S., Felicki, A., Nowotarski, B., Puzyna, W., Surówka, K.,Zachariasz, I., Zawicki, M. (2014). Narastajace dysfunkcje, zasadnicze dylematy, konieczne działania. Raport o stanie samorzadności terytorialnej w Polsce, vol. II. Kraków: Małopolska Szkoła Administracji Publicznej, UEK.

Boudon, R. (2009). Logika działania społecznego. Kraków: Zakład Wydawniczy Nomos.

Ocena sytuacji samorzadów lokalnych. (2013). Warsaw: Ministerstwo Administracji i Cyfryzacji. Retrieved from: http://mac.gov.pl/wp-content/uploads/2011/12/Ocena-sytuacji-samorz\%C4\%85d\%C3\%B3wlokalnych.pdf and http://eregion.wzp.pl/sites/default/files/ocena-sytuacji-samorzadow-lokalnych.pdf Gawłowski, R. (2012). Fragmentaryzacja terytorialna jako problem; wspótpraca jednostek samorządu terytorialnego jako rozwiązanie?. In A. Lutrzykowski (ed.), Ustrój terytorialny państwa a decentralizacja systemu władzy publicznej (pp. 164-176). Toruń: Wydawnictwo Adam Marszałek.

Gilowska, Z., Płoskonka, J., Prutis S., Stec, M., Wysocka, E., (1997). Model ustrojowy województwa (regionu) w unitarnym państwie demokratycznym. Samorząd Terytorialny, No. 8-9, pp. 5-24.

Grzybowska, M. (2013). Polska reforma samorzadowa - założenia i rezultaty. In M. Grzybowski, G. Kuca, 
P. Mikuli (eds.), Ustroje. Historia i współczesność. Polska-Europa-Ameryka Łacińska (pp. 647-660). Kraków: Wydawnictwo Uniwersytetu Jagiellońskiego.

Gwiazda, A. (2015). Problemy demograficzne Polski. Świat Idei i Polityki, No. 14, pp. 372-390. Retrieved from: https://repozytorium.ukw.edu.pl/bitstream/handle/item/4192/Problemy\%20demograficzne\%20 Polski.pdf? sequence $=1$ \&isAllowed $=\mathrm{y}$

Habuda, L. (2012). Zasadniczy podział terytorialny państwa podstawa dla wyboru w kwestii centralizacji i decentralizacji. In A. Lutrzykowski (ed.), Ustrój terytorialny państwa a decentralizacja systemu władzy publicznej (pp. 53-81). Toruń: Wydawnictwo Adam Marszałek.

Informacja Rzadu o stanie realizacji reformy samorzadu terytorialnego i administracji. (1999). Warsaw: Ministerstwo Spraw Wewnętrznych i Administracji.

Jaroszyński, M. (1936). Rozważania ideologiczne i programowe na temat samorządu. Samorząd, No. 20, 21, 23, reprint 1990, pp. 3-24.

Kachniarz, M., Babczuk, A. (2014). Ekspertyza: Ocena podziału terytorialnego państwa z uwzględnieniem efektywności funkcjonowania urzędów organów jednostek samorządu terytorialnego - wnioski i rekomendacje, Retrieved from: https://www.nist.gov.pl/files/zalacznik/1452372230_ocenpodziału.pdf

Kamiński, R. (2012). Centralizacja i decentralizacja w systemie władzy państwowej jako problem organizacyjny i prawny. Civitas Hominibus Rocznik Filozoficzno-Społeczny, 7(1), pp. 51-64.

Kamiński, R. (2014a). Organizacja terytorialna państwa a zdolność jednostek samorządowych do wykonywania zadań publicznych. Błędy, wnioski, niezbędne korekty, potrzebne zmiany. Civitas Hominibus Rocznik Filozoficzno-Społeczny, 9(1), pp. 69-84.

Kamiński, R. (2014b). Samorząd terytorialny III Rzeczypospolitej Polskiej. Odbudowa i jej efekty. Łódź: Wydawnictwo Akademii Humanistyczno-Ekonomicznej.

Knosala, E. (2006). Zarys nauki administracji. Kraków: Wydawnictwo Wolters Kluwer.

Konstytucja Rzeczypospolitej Polskiej z dnia 2 kwietnia 1997 r. uchwalona przez Zgromadzenie Narodowe w dniu 2 kwietnia 1997r., przyjęta przez Naród w referendum konstytucyjnym w dniu 25 maja 1997 r., podpisana przez Prezydenta Rzeczypospolitej Polskiej w dniu 16 lipca 1997r. (Dz.U. 1997 nr 78 poz. 483 z późn. zm.).

Wyrok Trybunału Konstytucyjnego z dnia 8 kwietnia 2009r., sygn. Akt K 37/06 (Dz.U. 2009, nr 63, poz. 532.). Kulesza, M. (1994). Reforma administracji publicznej - decentralizacja państwa.Wspólnota, No. 20,pp.3-4. Kulesza, M. (1998). Kryteria podziału powiatowego. Wspólnota, No. 12, pp. 10.

Ludność. Stan i struktura w przekroju terytorialnym w 2017r. Stan w dniu 31.XII.2016r. Główny Urząd Statystyczny. (2017). Retrieved from: http://stat.gov.pl/obszary-tematyczne/ludnosc/ludnosc/ludnoscstan-i-struktura-oraz-ruch-naturalny-w-przekroju-terytorialnym-w-2017-r-stan-w-dniu-31-xii,6,23. html

Podstawowe kryteria podziału terytorialnego kraju na powiaty i województwa. (1998). Warsaw: Departament Reform Ustrojowych Państwa KPRM.

Powierzchnia i ludność w przekroju terytorialnym w 2016r. Retrieved from: https://stat.gov.pl/obszarytematyczne/ludnosc/ludnosc/powierzchnia-i-ludnosc-w-przekroju-terytorialnym-w-2016-r-,7,13. html

Prognoza ludności rezydującej dla Polski na lata 2015-2050. Retrieved from: https://stat.gov.pl/ obszary-tematyczne/ludnosc/prognoza-ludnosci/prognoza-ludnosci-rezydujacej-dla-polski-nalata-2015-2050,8,1.html

Regulski, J. (2013). Kilka uwag i refleksji na tle raportu „Narastajace dysfunkcje. Zasadnicze dylematy, konieczne działania. Warsaw: Fundacja Rozwoju Demokracji Lokalnej. Retrieved from: http://www. frdl.szczecin.pl/manager_pliki/18/Uwagi_o_raporcie_prof_Jerzego_Hausnera.pdf 
Rozporządzenie Rady Ministrów z dnia 29 lipca 2014r. w sprawie połaczenia gmin, ustalenia granic niektórych gmin i miast, nadania niektórym miejscowościom statusu miasta oraz zmiany siedziby władz gminy (Dz.U. 2014 poz. 1023).

Samorzą jako pracodawca. Raport o zatrudnieniu w sektorze samorządowym. Poznań: Związek Miast Polskich. Retrieved from: http://www.miasta.pl/uploads/document/content_file/90/Samorz_d_jako_ pracodawca._Raport_o_zatrudnieniu_w_sektorze_samorz_dowym._Pozna__2014.pdf

Sawicka, K. (2013). Finanse samorzadu terytorialnego - podstawy wyodrębnienia, struktura. In J. Korczak Województwo - region - regionalizacja. 15 lat po reformie terytorialnej i administracyjnej, II Wydziałowa Konferencja Kół Naukowych Wydziału Prawa, Administracji i Ekonomii, Wrocław 21-22 listopada 2013r. (pp. 53-81).e-Monografie, Wrocław: Prawnicza i Ekonomiczna Biblioteka Cyfrowa. Retrieved from: http://www.repozytorium.uni.wroc.pl/Content/42900/Wojewodztwo_region_regionalizacja.pdf

Sprawozdania z wykonania budżetu państwa za okres od 1 stycznia 2006r. do 31 grudnia 2015r. Informacja o wykonaniu budżetów jednostek samorządu terytorialnego, Rada Ministrów. Warsaw 2007-2016. Retrieved from: http://www.mf.gov.pl/ministerstwo-finansow/dzialalnosc/finanse-publiczne/budzetpanstwa/wykonanie-budzetu-panstwa/sprawozdanie-z-wykonania-budzetu-panstwa-roczne

Sprawozdanie z wykonania budżetu państwa za okres od 1 stycznia do 31 grudnia 2016r. Informacja o wykonaniu budżetów jednostek samorządu terytorialnego. Rada Ministrów. Warsaw 2017. Retrieved from: https://www.mf.gov.pl/c/document_library/get_file?uuid=1c0aeb75-1202-4ee5-844fa0d7bda03eee\&groupId=764034

Wysocka, E., Koziński, J. (1998). Przesłanki regionalizacji. Zarys strategii rozwoju i polityki przestrzennej. Warsaw: IGPiK.

\section{Author}

\section{Radosław Kamiński}

PhD - Instytut Nauk Społeczno-Humanistycznych, Wydział Finansów i Zarządzania, Wyższa Szkoła Bankowa we Wrocławiu. Contact details: kaminski.radoslaw@interia.pl 